\title{
Clinical applications of serum carcinoembryonic antigen and alpha-fetoprotein levels in children with solid tumours
}

\author{
J. R. MANN, G. E. LAKIN, J. C. LEONARD, H. A. RAWLINSON, S. G. N. RICHARDSON, \\ J. J. CORKERY, A. H. CAMERON, AND K. J. SHAH
}

From Birmingham Children's Hospital; Department of Experimental Pathology, University of Birmingham; and Department of Medical Genetics, Royal Hospital for Sick Children, Glasgow

SUMMARY A study was carried out on serum carcinoembryonic antigen (CEA) and alpha-fetoprotein (AFP) levels, both measured by radioimmunoassay, in 88 children with malignant solid tumours and in 26 children with nonmalignant disorders, who presented during the years 1973-77. Slightly or moderately raised CEA levels were found at presentation in 11 of 66 children with malignant tumours, in 2 others with recurrent tumours, and in 4 children with nonmalignant disorders. Raised CEA levels generally indicated advanced malignant disease, often affecting the liver, or other hepatic disorders, but were not associated with a specific tumour type.

Except in the first months of life, significantly raised AFP levels were detected only in 11 patients with yolk sac-derived tumours, or hepatomas, and in one child with tyrosinosis who later developed a malignant hepatoma. Serial measurements of AFP accurately reflected the clinical response to treatment and in 2 patients indicated recurrence before this could be detected clinically.

Carcinoembryonic antigen (CEA), a glycoprotein, was first found as an apparently specific surface antigen associated with adenocarcinoma of the human colon by Gold and Freedman (1965). However, although about $70 \%$ of patients with gastrointestinal malignancy have raised levels, raised CEA has since been found in patients with other adult cancers (Booth et al., 1973; Neville and Laurence, 1974) and certain nonmalignant disorders. Nevertheless, serial studies have shown that in adult patients with CEA-releasing colorectal carcinomas serum levels fall if treatment is successful and rise again when metastases occur (Booth et al., 1974). Studies of serum CEA in children with neuroblastoma (Reynoso et al., 1972; Wang et al., 1974; Frens et al., 1976) showed that serum CEA levels were usually raised when active tumour was present and fell when treatment was successful. That CEA may act as a tumour marker in paediatric malignancy was also suggested by Felberg et al. (1976), who found raised levels in retinoblastoma patients.

Alpha-fetoprotein (AFP), a fetal protein chemically similar to albumin, was first identified by

Received 7 October 1977
Pedersen in 1944. Raised serum levels were described in association with hepatomas in rodents (Abelev et al., 1963) and humans (Tatarinov, 1964) and in patients with malignant gonadal teratoblastomas (Abelev et al., 1967). Raised levels have also been found in patients with certain nonmalignant disorders (Neville and Cooper, 1976). Early studies (Abelev et al., 1967; Masopust et al., 1968; Mawas et al., 1969) of over 300 children with malignant tumours, using comparatively insensitive bidimensional immunodiffusion methods, showed detectably raised levels in a proportion of children with teratomata, gonadal embryonal carcinomata, hepatoblastoma, and hepatocellular carcinoma, but in none with the commoner tumours such as neuroblastoma and nephroblastoma. Radioimmunoassay has increased the sensitivity of the test by more than 1000-fold, and has permitted the detection of AFP in sera from most children with yolk sac-derived and hepatic malignancies.

Studies in some 30 paediatric cancer patients suggest that AFP monitoring by this sensitive method may be of value during treatment (Hagesawa et al., 1972, 1973; Takahashi, 1973; Itoh et al., 1974; Kohn and Weaver, 1974; Teilum et al., 1974; Pick et al., 1975; Nørgaard-Pedersen et al., 1975, 
1976; Tsuchida et al., 1975; Palmer et al., 1976; Urano et al., 1976; Shirai et al., 1976; Sakashita et al., 1976; Schoenfeld et al., 1976; Grigor et al., 1977).

The purpose of our study was to define the frequency of raised serum CEA and AFP levels, both measured by radioimmunoassay, in children with malignant solid tumours, and to assess the clinical value of serial measurements in monitoring response to therapy and detecting tumour recurrence. We also report the findings in 25 children with nonmalignant disorders.

\section{Patients and methods}

Eighty-eight children referred during 1973-77 for treatment of malignant solid tumours and 26 children being investigated or treated for what proved to be nonmalignant conditions were studied. In patients found to have raised CEA or AFP levels serial venepunctures were performed to assess the relationship between the serum levels and response to therapy. In other patients blood for CEA and AFP levels was taken during venepuncture for other investigations, or for the administration of cytotoxic drugs. The patients' ages ranged from 5 days to 15 years, 11 being aged less than one year, and their diagnoses are shown in Tables 1 and 2.

CEA levels were measured by the double-antibody technique, the $95 \%$ confidence limits of normal healthy adults being $0-15 \mathrm{ng} / \mathrm{ml}$, standard error 1.9 (Booth et al., 1974). In some patients a comparison was made, using the same sera, with CEA levels measured by the Z-gel method (Lo Gerfo et al., 1971), the normal upper limit in healthy adults being $2.5 \mathrm{ng} / \mathrm{ml}$, the reproducibility of the CEA Roche assay being $\pm 0.5 \mathrm{ng} / \mathrm{ml}$ at this level.

AFP levels, normally less than $25 \mathrm{ng} / \mathrm{ml}$ in adults (Grigor et al., 1977), were measured by radioimmunoassay. In the first 18 patients AFP

Table 1 Details of patients with malignant tumours

\begin{tabular}{|c|c|}
\hline & No. of patients \\
\hline $\begin{array}{l}\text { Lymphoma } \\
\text { (lymphosarcoma 7, histiocytic lymphoma 2, } \\
\text { Hodgkin's disease 4) }\end{array}$ & 13 \\
\hline Wilms's tumour & 26 \\
\hline $\begin{array}{l}\text { Mesenchymal tumours } \\
\text { (rhabdomyosarcoma 10, undifferentiated } \\
\text { sarcoma 3, leiomyosarcoma 1, fibrosarcoma 1) }\end{array}$ & 15 \\
\hline $\begin{array}{l}\text { Neuroblastoma } \\
\text { Yolk sac-derived tumours } \\
\text { (ovarian embryonal carcinoma 1, } \\
\text { orchioblastoma 4, sacrococcygeal teratoma 1; }\end{array}$ & $\begin{array}{r}12 \\
6\end{array}$ \\
\hline Hepatomas & 5 \\
\hline $\begin{array}{l}\text { Other tumours } \\
\text { (Ewing's sarcoma 2, medulloblastoma 1, } \\
\text { pulmonary blastoma 1, optic glioma 1, } \\
\text { ependymoma 1, branchial cleft carcinoma 1, } \\
\text { glomus tumour 1, uncertain } 3 \text { ) }\end{array}$ & 11 \\
\hline Total & 88 \\
\hline
\end{tabular}

estimations were done in the Department of Cancer Studies, University of Birmingham; in this laboratory the levels in healthy adult males and nonpregnant females were in the range 1-19 $\mathrm{ng} / \mathrm{ml}$ (mean \pm SD $9 \cdot 3 \pm 8 \cdot 6$ ). Sera from subsequent patients were tested in the Department of Medical Genetics, Glasgow, using the method of Vince et al. (1975), the lower limit of sensitivity varying from $<16.7$ to $<5.0 \mathrm{ng} / \mathrm{ml}$ (conversion of these results to units $/ 1 \times$ $10^{-3}$ using the international reference preparation (first British Standard Human Cord Serum 72/227) can be done by multiplying by $1 \cdot 5$ ).

\section{Results}

CEA. In the majority of patients the CEA levels measured by the double-antibody technique were normal (Fig. 1). Details of the 17 patients with levels $>15 \mathrm{ng} / \mathrm{ml}$ are given in Table 3.8 of the 17

Table 2 Details of patients with nonmalignant conditions

\begin{tabular}{ll}
\hline $\begin{array}{l}\text { Infections } \\
\text { (lymphadenopathy 3, toxoplasmosis 1, }\end{array}$ & 6 \\
osteomyelitis, 1, hydatid cysts 1) & \\
$\begin{array}{l}\text { Benign tumours } \\
\text { (teratomas 2, liver hamartoma 2, fibroma 1) }\end{array}$ & 5 \\
$\begin{array}{l}\text { Inflammatory disorders } \\
\text { (rheumatoid arthritis 2, ulcerative colitis 1, }\end{array}$ & 4 \\
sinus histiocytosis 1) & 2 \\
Fanconi's anaemia & 2 \\
Twin of child with tumour & 1 \\
Tyrosinosis & 6 \\
Other nonmalignant disorders & 26 \\
Total & 2 \\
\hline
\end{tabular}

Table 3 Patients with raised serum $C E A$ levels $(>15 \mathrm{ng} / \mathrm{ml})$

\begin{tabular}{|c|c|c|c|}
\hline $\begin{array}{l}\text { Age } \\
\text { (years) }\end{array}$ & $\operatorname{Sex}$ & $\begin{array}{l}\text { CEA level } \\
(n g / m l)\end{array}$ & Diagnosis \\
\hline $13 \cdot 0$ & $\mathbf{M}$ & $34 \cdot 5$ & $\begin{array}{l}\text { Fanconi's anaemia; jaundice; } \\
\text { oxymetholone therapy; died } 1 \text { year } \\
\text { later of leukaemia }\end{array}$ \\
\hline $7 \mathrm{w}$ & $\mathbf{M}$ & $29 \cdot 5$ & Multiple osteomyelitis \\
\hline $4 \cdot 4$ & $\mathbf{M}$ & $18 \cdot 0$ & $\begin{array}{l}\text { Tyrosinosis; hepatoma (but included with } \\
\text { nonmalignant disorders in Fig. 1) }\end{array}$ \\
\hline $1 \cdot 8$ & $\mathbf{M}$ & $21 \cdot 3$ & Hamartoma of liver \\
\hline $3 \cdot 9$ & $\mathbf{M}$ & $19 \cdot 0$ & Histiocytic lymphoma; jaundice \\
\hline $10 \cdot 2$ & $\mathbf{F}$ & $18 \cdot 0$ & Histiocytic lymphoma \\
\hline $15 \cdot \overline{8}$ & $\mathbf{F}$ & $19 \cdot 0$ & $\begin{array}{l}\text { Relapsed Hodgkin's disease; hepatic } \\
\text { involvement }\end{array}$ \\
\hline $\begin{array}{l}7 \cdot 1 \\
4 \cdot 7\end{array}$ & $\underset{\mathbf{F}}{\mathbf{M}}$ & $\begin{array}{l}16 \cdot 5 \\
19 \cdot 8\end{array}$ & $\begin{array}{l}\text { Stage I Wilms's tumour } \\
\text { Stage III Wilms's tumour; hepatic failure }\end{array}$ \\
\hline $2 \cdot 5$ & $\mathbf{M}$ & $17 \cdot 3$ & Stage II Wilms's tumour \\
\hline $7 \cdot 5$ & $\mathbf{F}$ & $15 \cdot 5$ & Thoracic mesenchymal tumour. \\
\hline 0.9 & $\mathbf{M}$ & $25 \cdot 3$ & $\begin{array}{l}\text { Stage IV neuroblastoma; hepatic } \\
\text { involvement }\end{array}$ \\
\hline $11 \cdot 7$ & $\mathbf{F}$ & $15 \cdot 3$ & Ovarian embryonal carcinoma \\
\hline $1 \cdot 8$ & $\mathbf{M}$ & $21 \cdot 3$ & Orchioblastoma (see text) \\
\hline $2 \cdot 7$ & $\mathbf{F}$ & $23 \cdot 3$ & $\begin{array}{l}\text { Hepatoma (bile duct tumour); jaundice; } \\
\text { incomplete resection; CEA } 25 \text { before } \\
\text { death }\end{array}$ \\
\hline $1 \cdot 3$ & $\mathbf{F}$ & 31 & Hepatoblastoma, recurrent \\
\hline $2 \cdot 0$ & $\mathbf{M}$ & $17 \cdot 5$ & Pulmonary blastoma \\
\hline
\end{tabular}




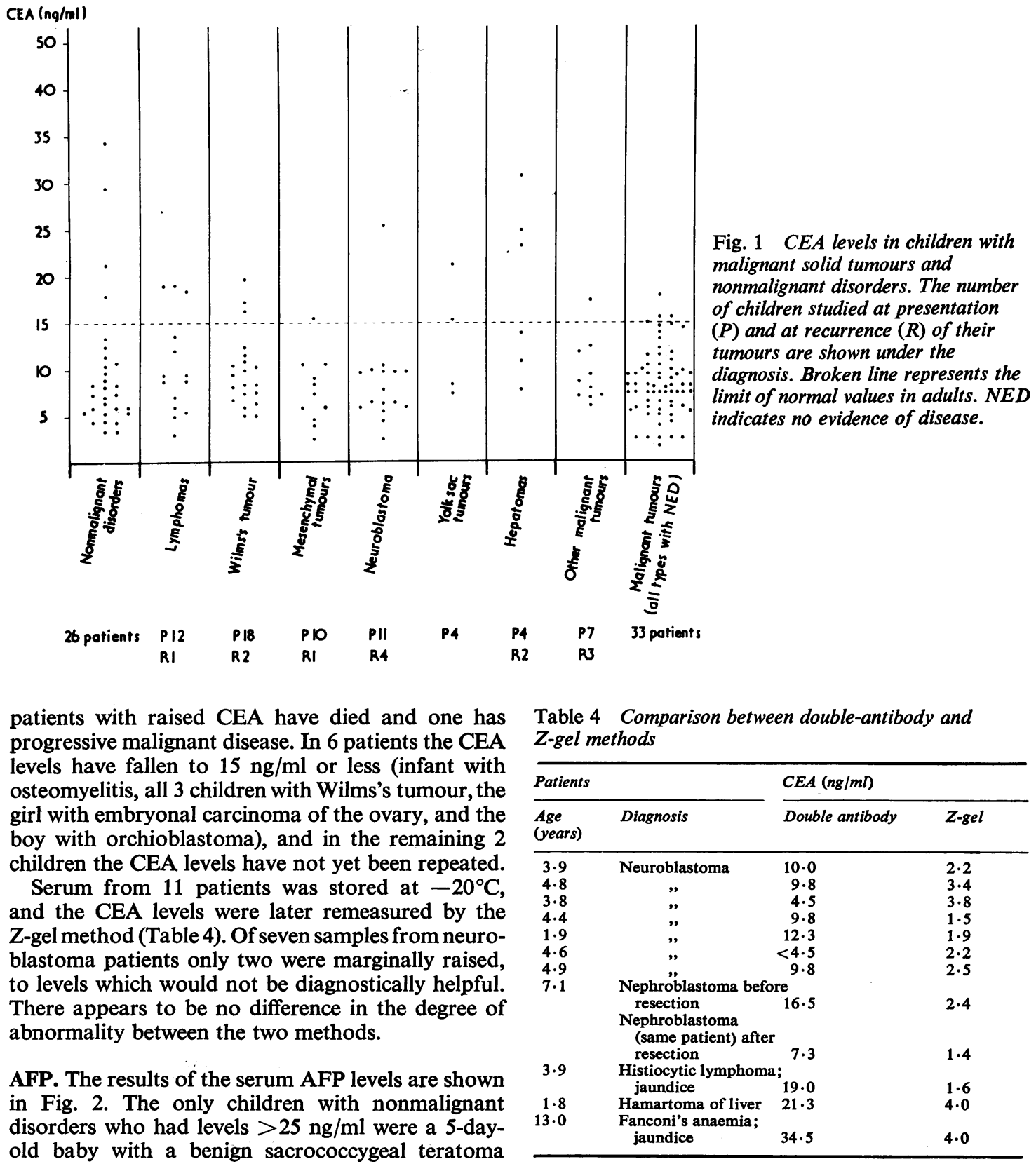

$(9500 \mathrm{ng} / \mathrm{ml})$, a 7-week-old infant with osteomyelitis (117 $\mathrm{ng} / \mathrm{ml})$, a 9-week-old baby with a benign fibroma $(120 \mathrm{ng} / \mathrm{ml})$, and a boy with tyrosinosis aged 1.3 years $(28000 \mathrm{ng} / \mathrm{ml})$. The raised values in the 3 infants were normal for their ages, and in the first 2 had fallen to $<25 \mathrm{ng} / \mathrm{ml}$ when remeasured at ages 3 and 7 months respectively. Although raised AFP levels have been described in tyrosinosis (Bélanger

et al., 1973), it is notable that our patient was found to have an unsuspected malignant hepatoma at necropsy 3 years after the AFP level was measured. 2 of Bélanger's patients developed hepatocarcinoma terminally, their AFP levels paralleling tumour growth (Bélanger et al., 1976). Among the children with malignant tumours, grossly raised serum AFP 


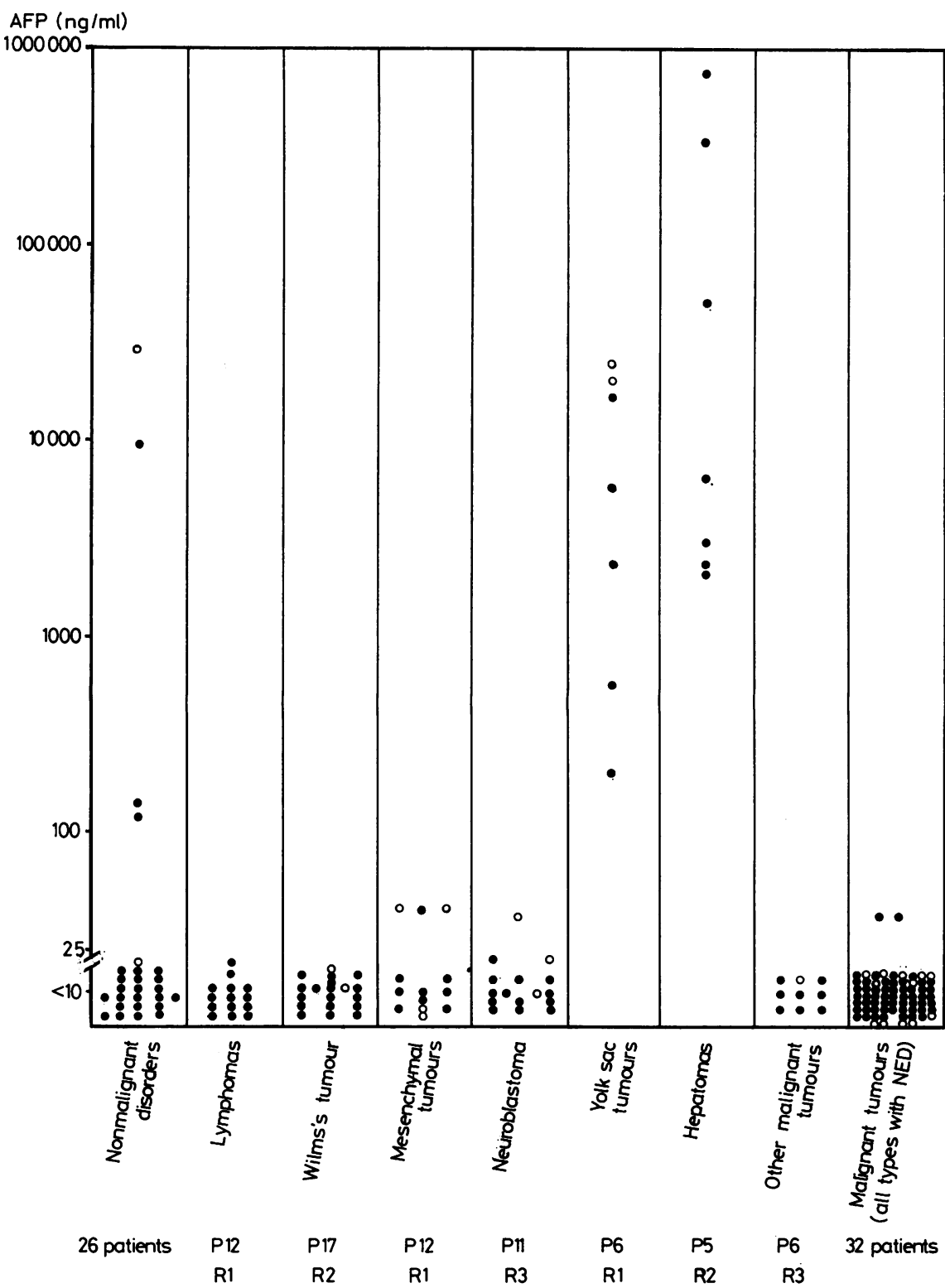

Fig. 2 AFP levels in children with malignant solid tumours and nonmalignant disorders. The number of children studied at presentation $(P)$ and at recurrence $(R)$ of their tumours are shown under the diagnosis. NED indicates no evidence of disease. $\bullet=$ levels measured in Glasgow; $0=$ levels measured in Birmingham.

was found only in children with yolk sac-derived (malignant teratoma, orchioblastoma, ovarian embryonal carcinoma) or hepatic tumours (Table 5).

A slight rise in serum AFP was present in 2 boys aged 5 and 9.5 years with alveolar rhabdomyosarcoma (42 and $45 \mathrm{ng} / \mathrm{ml}$ ), and in a boy aged 4 years with neuroblastoma $(36 \mathrm{ng} / \mathrm{ml})$. The AFP subsequently fell below $25 \mathrm{ng} / \mathrm{ml}$ in all 3 boys although only the first child's tumour responded to treatment.
A level of $43 \mathrm{ng} / \mathrm{ml}$ was detected in a 9-week-old baby with pelvic fibrosarcoma, and his AFP remained for some time above the adult normal range $(37 \mathrm{ng} / \mathrm{ml}$ at age 3 and 5.5 months) but was undetectable by 7 months of age, when there was still no evidence of recurrent tumour. None of the other children with malignant tumours had raised AFP levels at presentation, at recurrence, or after successful treatment. 
Serial AFP levels. In the children with yolk sacderived and hepatic malignant tumours serial AFP levels correlated well with disease status, generally falling to $<25 \mathrm{ng} / \mathrm{ml}$ within a month of successful resection but remaining raised if resection was incomplete. For example, in a boy aged 1.7 years

Table 5 Children with malignant tumours and grossly raised $A F P$

\begin{tabular}{|c|c|c|c|}
\hline $\begin{array}{l}\text { Age } \\
\text { (years) }\end{array}$ & Sex & $\begin{array}{l}A F P \\
(n g / m l)\end{array}$ & Comment \\
\hline $1 \cdot 7$ & $\mathbf{M}$ & 20000 & Sacrococcygeal teratoma (see text) \\
\hline 0.9 & $\mathbf{M}$ & 204 & $\begin{array}{l}\text { Orchioblastoma, } 5 \text { days after resection; } \\
\text { disease-free with normal AFP } 17 \text { months } \\
\text { later }\end{array}$ \\
\hline $1 \cdot 8$ & $\mathbf{M}$ & 2300 & Orchioblastoma (see text) \\
\hline $5 \cdot 0$ & $\mathbf{M}$ & 5400 & Orchioblastoma \\
\hline 0.5 & $\mathbf{M}$ & 540 & $\begin{array}{l}\text { Orchioblastoma, } 13 \text { days after resection } \\
\text { (see text) }\end{array}$ \\
\hline $11 \cdot 7$ & $\mathbf{F}$ & 17000 & $\begin{array}{l}\text { Embryonal carcinoma of ovary, } 6 \mathrm{~d} \text { after } \\
\text { incomplete resection (see text) }\end{array}$ \\
\hline $2 \cdot 7$ & $\mathbf{F}$ & 2300 & $\begin{array}{l}\text { Hepatoma (bile duct tumour); incomplete } \\
\text { resection; AFP rose to } 54300 \text { before } \\
\text { death }\end{array}$ \\
\hline $1 \cdot 8$ & $\mathbf{M}$ & 2200 & $\begin{array}{l}\text { Hepatoblastoma removed; disease-free with } \\
\text { normal AFP } 2 \text { years later }\end{array}$ \\
\hline $1 \cdot 3$ & $\mathbf{F}$ & 778000 & Hepatoblastoma (see text) \\
\hline $7 \cdot 7$ & $\mathbf{F}$ & 3000 & $\begin{array}{l}\text { Unresectable hepatoblastoma; died after } \\
\text { biopsy }\end{array}$ \\
\hline $26 \mathrm{~d}$ & $\mathbf{M}$ & 330000 & Hepatoblastoma; died after resection \\
\hline
\end{tabular}

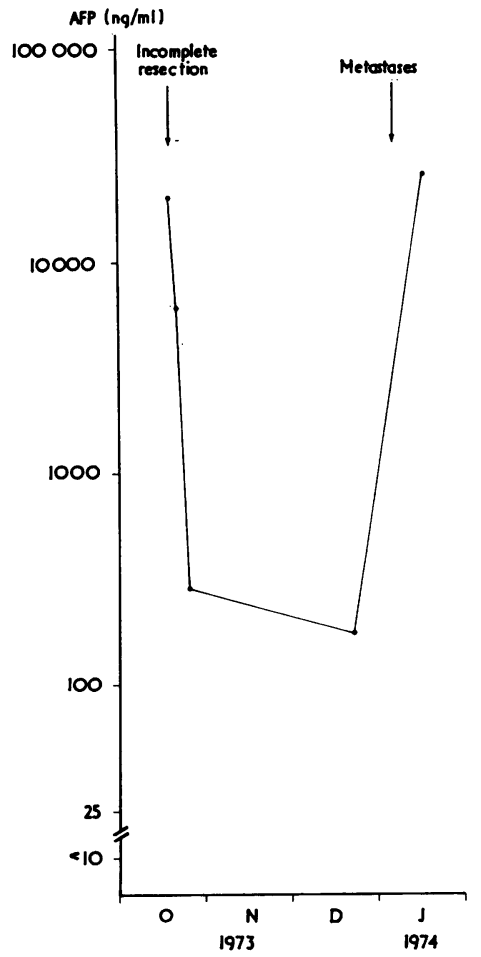

Fig. 3 Boy aged 1.7 years with malignant sacrococcygeal teratoma. who had incomplete resection of a malignant sacrococcygeal teratoma, AFP levels fell but never returned to normal, and rose again before death from metastases (Fig. 3).

In a boy aged 1.8 years with orchioblastoma, serum levels fell rapidly to normal after successful resection (Fig. 4). His CEA levels also fell, but less promptly. Another boy aged 6 months with orchioblastoma had AFP levels of 540, 46, and $10 \mathrm{ng} / \mathrm{ml}$, 13,28 , and 41 days after apparently successful resection. However, the level 4.5 months after resection rose to $3060 \mathrm{ng} / \mathrm{ml}$; despite the absence of abnormal clinical findings when this blood specimen was taken, 16 days later he developed a pathological fracture of the femur and the presence of multiple skeletal metastases was confirmed by $x$-rays and needle aspirate.

An 11-year-old girl with embryonal carcinoma of the ovary had the primary tumour resected, but metastatic nodules were present in the peritoneal cavity. These were treated by whole abdominal irradiation and chemotherapy with vincristine, actinomycin D, and cyclophosphamide. Her AFP levels fell to normal (Fig. 5) and she remains clinically free of disease 33 months from the start of

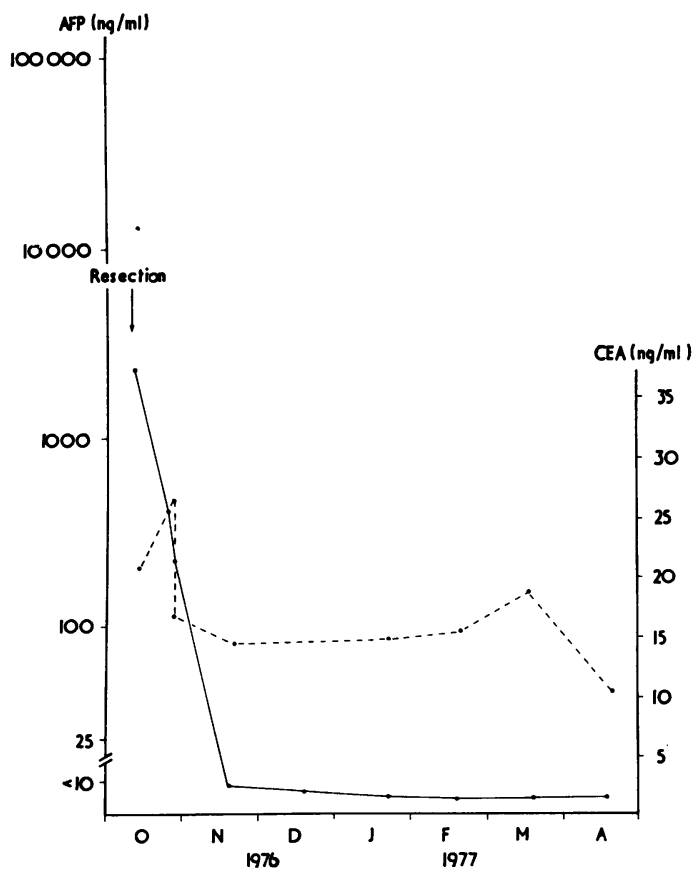

Figs. 4-6 AFP levels are shown as solid lines and $C E A$ levels as broken lines.

Fig. 4 Boy aged $1 \cdot 8$ years with orchioblastoma. 


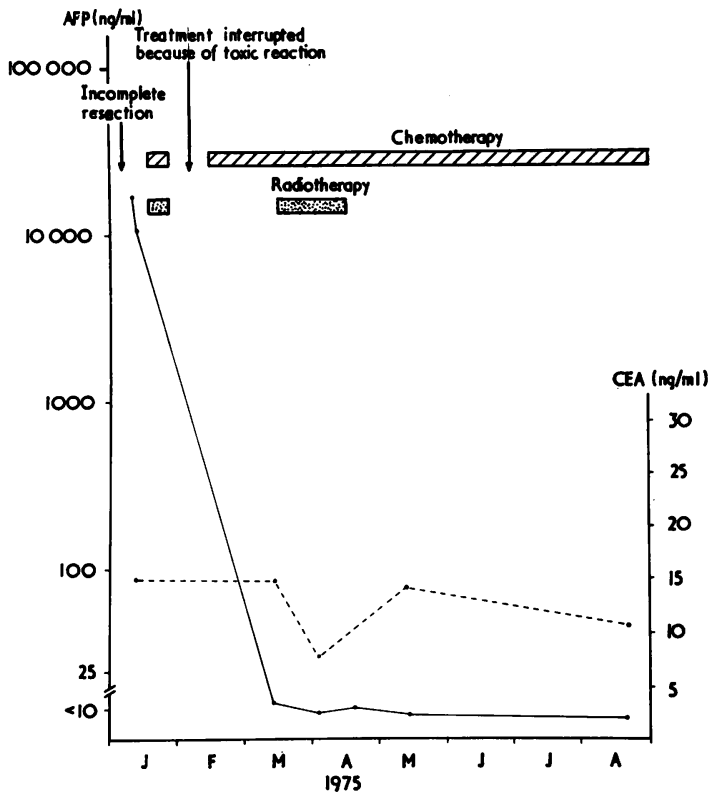

Fig. 5 Girl aged 11 years with embryonal carcinoma of ovary.

treatment, chemotherapy having been stopped after 24 months.

Apparently complete resection of a hepatoma in a girl aged 1.3 years was followed by a sharp fall in serum AFP levels (Fig. 6). Postoperatively right phrenic palsy occurred but thoracotomy revealed no cause. Her AFP levels did not return to normal and then rose again. Extensive investigations, including chest and skeletal radiography, bone marrow aspirate, liver scan, hepatic angiography, and another laparotomy failed to demonstrate recurrence. However, 2 months later metastases were visible in both lungs on chest $x$-rays. Chemotherapy with actinomycin $\mathbf{D}$ and adriamycin led to temporary disappearance of the metastases and a fall in AFP level, but she also became jaundiced. As the AFP levels rose the pulmonary metastases again became visible. The jaundice faded after actinomycin and adriamycin therapy were stopped but AFP continued to rise and the pulmonary metastases slowly enlarged, despite treatment with cyclophosphamide, and she died. Her CEA levels also reflected the clinical course, though less closely than did the AFP.

\section{Discussion}

The best established biochemical marker of paediatric malignancy is the raised urinary catecholamine excretion in patients with neuroblastoma (Marsden and Steward, 1976). The usefulness of measuring

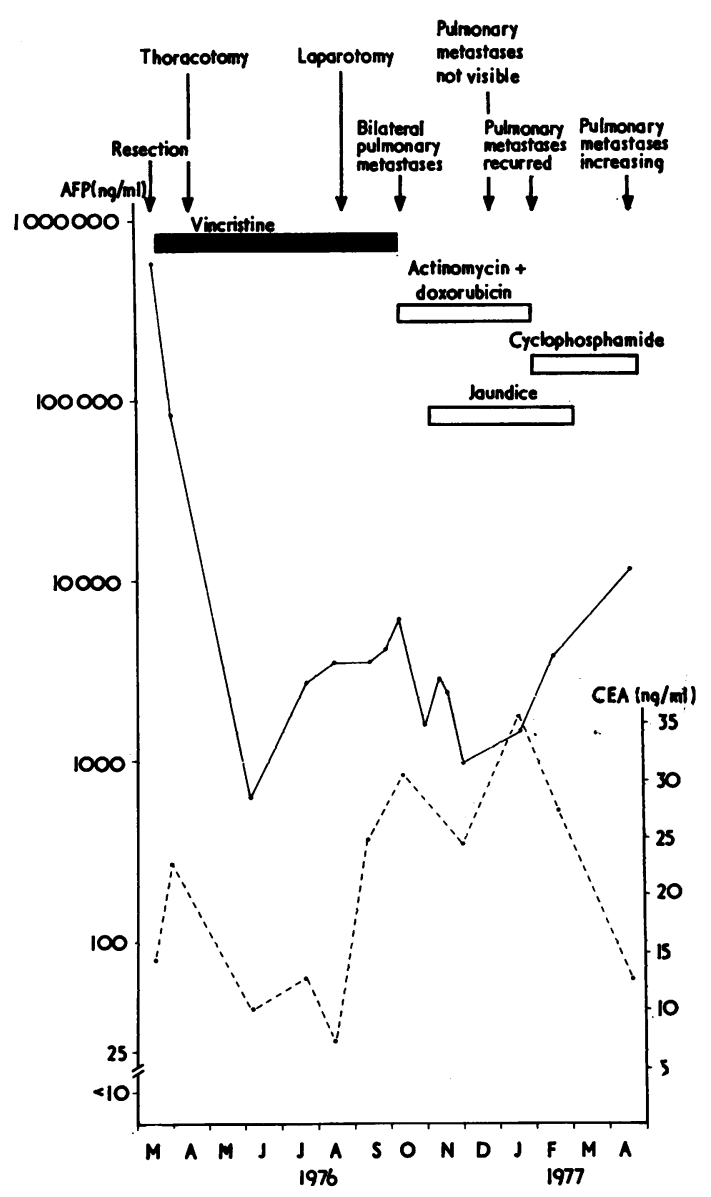

Fig. 6 Girl aged $1 \cdot 3$ years with hepatoblastoma.

CEA levels in paediatric malignancy has not been well assessed, although 16 of 19 children with active neuroblastoma were reported to have raised levels which fell to normal if treatment was successful (Reynoso et al., 1972; Wang et al., 1974; Frens et al., 1976). 4 of 5 retinoblastoma patients had raised CEA levels which fell after enucleation, and raised levels were found in $29.7 \%$ of their nonaffected family members (Felberg et al., 1976).

In our study we have found raised CEA levels in 13 of 68 children with malignant solid tumours. In general the rise has been small and no patient had levels in the range (>50 ng/ml) commonly found in adults with gastrointestinal cancer (Booth et al., 1973). There was no specificity for any tumour type, a small proportion of children with lymphomas, Wilms's tumour, mesenchymal tumours, neuroblastoma, yolk sac tumours, hepatomas, and other tumours having raised levels. 
It is interesting that only one of our 12 patients with active neuroblastoma had a raised level, in view of the much higher proportion in the American series (Reynoso et al., 1972; Wang et al., 1974; Frens et al., 1976). This difference cannot be explained by a smaller tumour load in our patients, since 8 had stage IV disease (7 have died) and of the 4 who did not have detectable metastases at presentation, 2 have since died of recurrence. Our findings may differ from the Americans' by chance, but alternatively may be related to our assay technique, as the Z-gel method was used for the American work. We therefore remeasured by the Z-gel technique all samples still available from neuroblastoma patients and a few others. The finding of normal or only slightly raised values confirmed the findings from the double-antibody assay, thus eliminating a methodological explanation.

In 5 of the 13 children with malignant tumours and raised CEA, the levels returned to normal after successful treatment; one of these was a girl with Wilms's tumour who was in liver failure due to interference by the tumour with the hepatic blood supply. However, raised CEA was associated in 7 children with advanced disease which could not be cured; 5 children in this group had primary or secondary hepatic tumours.

The 4 children with 'benign' disorders who had raised CEA are of special interest. One had successful removal of a hamartoma of the liver; however, the other child in the series with liver hamartoma had a normal CEA level. Another boy had Fanconi's anaemia and jaundice associated with oxymetholone therapy, which may also have induced the growth of a benign hepatoma; he died later of leukaemia and is reported elsewhere (Obeid et al., 1978). The third child who had tyrosinosis died from portal hypertension shortly after the CEA estimation and was found at necropsy to have an unsuspected malignant hepatoma. The fourth was an infant aged 7 weeks with multiple staphylococcal osteomyelitis whose level subsequently fell to $8 \cdot 5 \mathrm{ng} / \mathrm{ml}$.

In summary, therefore, children do not usually have raised CEA levels when they are first seen with malignant disease. The detection of raised CEA levels generally indicates advanced malignant disease, often involving the liver, or other hepatic disorders.

AFP is a product of the fetal liver, gastrointestinal tract, and yolk sac. Its synthesis reaches a peak around the 13th week of gestation, when serum levels of $3-4 \mathrm{mg} / \mathrm{ml}$ are found. The level then decreases progressively to about $30 \mu \mathrm{g} / \mathrm{ml}$ at birth. By the end of the sixth month the level is usually less than $50 \mathrm{ng} / \mathrm{ml}$, and from the age of 2 years through adulthood the normal serum levels are $2 \cdot 6 \pm 1.6(\mathrm{SD}) \mathrm{ng} / \mathrm{ml}$ (Neville and Cooper, 1976;
Elgort et al., 1976). The half-life of the protein in the circulation has been calculated to be between 4 and 9 days, and levels generally fall to the normal range within a month of successful resection of an AFPproducing tumour (Mawas et al., 1969; Hagesawa et al., 1973; Grigor et al., 1977). Caution is required in the interpretation of AFP levels during the first year of life since, using a gel precipitation method, Elgort et al. (1976) found high levels in $79 \%$ of infants with viral hepatitis and slightly raised levels $(15-250 \mathrm{ng} / \mathrm{ml})$ in some children aged less than one year with nonhepatic, nonmalignant disorders and with nonyolk sac, nonhepatic tumours. Even after one year of age $13 \%$ of their patients with Wilms's tumour and $5.8 \%$ of their patients with neuroblastoma had AFP levels of between 15 and 250 $\mathrm{ng} / \mathrm{ml}$. Other disorders which are associated with high serum AFP levels in childhood are Indian childhood cirrhosis (Nayak et al., 1972), hepatitis (Chandra, 1973), certain other non-neoplastic liver and inflammatory bowel diseases (Neville and Cooper, 1976), ataxia telangiectasia (Waldmann and McIntire, 1972), and tyrosinosis (Bélanger et al., 1973).

However, in practice, after the first month of life we have found that it is usually possible to exclude on clinical grounds the other conditions which cause raised AFP when a yolk sac or hepatic tumour is suspected. Moreover, these malignancies generally produce very high serum AFP levels, well outside the physiological range, thus permitting prediction of the histological type of a tumour before surgery.

All our 11 patients with yolk sac and hepatic malignancies had raised AFP levels at presentation which fell to normal if treatment was successful. It is clear that serial levels, especially if measured by radioimmunoassay, may be useful in the detection of recurrence before this is evident clinically, as shown in 2 of our patients and by others (Hagesawa et al., 1972; Kohn and Weaver, 1974; NørgaardPedersen et al., 1975; Grigor et al., 1977). This is important because recurrent or residual disease detected initially by raised serum AFP may occasionally be curable (Grigor et al., 1977). However these authors also point out that in adult males with germ cell tumours, recurrent or progressive disease may be present in the absence of raised AFP levels, presumably because non-yolk sac elements of teratomas are responsible for recurrence in some patients. Further serial studies are required to determine whether this is also true in children.

We gratefully acknowledge the assistance of Professor D. G. Harnden, Dr J. Julian, and Mrs K. Vause, Department of Cancer Studies, University of Birmingham; Dr P. W. Dykes, Department of 
Experimental Pathology, University of Birmingham; Professor M. A. Ferguson-Smith, Department of Medical Genetics, Royal Hospital for Sick Children, Glasgow; Dr J. G. Ratcliffe, Department of Biochemistry, Glasgow Royal Infirmary; Mr P. Gornall, Mr A. Gourevitch, and Dr B. S. B. Wood, Birmingham Children's Hospital; Dr A. J. Banks, Queen Elizabeth Hospital, Birmingham; Dr P. M. Jones, Royal Manchester Children's Hospital; and all the paediatricians and surgeons in the West Midlands who referred patients to us.

\section{References}

Abelev, G. I., Perova, S. D., Khramkova, N. I., Postinkova, S. I., and Irlin, J. S. (1963). Production of embryonal alpha-globulin by transplantable mouse hepatomas. Transplantation, 1, 174-180.

Abelev, G. I., Assecritova, I. V., Kraevsky, N. A., Perova, S. D., and Perevodchikova, N. I. (1967). Embryonal serum alpha-globulin in cancer patients; diagnostic value. International Journal of Cancer, 2, 551-558.

Bélanger, L., Bélanger, M., Prive, L., Larochelle, J., Tremblay, M., and Aubin, G. (1973). Tyrosinémie héréditaire et alpha-1-foetoprotéine. I. Intêret clinique de l'alphafoeto-protéine dans la tyrosinémie héréditaire. Pathologie et Biologie, 21, 449-455.

Bélanger, L., Larochelle, J., Bélanger, M., and Prive, L. (1976). Tyrosinosis: hereditary persistence of alpha-1fetoprotein. Onco-developmental Gene Expression, pp. 155158. Ed. by W. H. Fishman and S. Sell. Academic Press, New York.

Booth, S. N., King, J. P. G., Leonard, J. C., and Dykes, P. W. (1973). Serum carcinoembryonic antigen in clinical disorders. Gut, 14, 794-799.

Booth, S. N., Jamieson, G. C., King, J. P. G., Leonard, J., Oates, G. D., and Dykes, P. W. (1974). Carcinoembryonic antigen in management of colorectal carcinoma. British Medical Journal, 3, 183-187.

Chandra, R. K. (1973). Hepatitis antigen and alpha-fetoprotein in neonatal hepatitis. Archives of Disease in Childhood, 48, 157-158.

Elgort, D. A., Abelev, G. I., Durnov, L. A., Pashkov, I. V., Levina, D. M., Laskina, A. V., Izrailskaya, M. A., Kharit, I. O., Ter-Grigorova, E. N., and Reizis, A. R. (1976). Alpha-fetoprotein in the diagnosis of tumours in children. (In Russian). Vestnik Akademii Meditsinskikn Nauk SSSR, No. 2, 31-44.

Felberg, N. T., Michelson, J. B., and Shields, J. A. (1976). CEA family syndrome. Abnormal carcinoembryonic antigen (CEA) levels in asymptomatic retinoblastoma family members. Cancer, 37, 1397-1402.

Frens, D. B., Bray, P. F., Wu., J. T., and Lahey, M. E. (1976). The carcinoembryonic antigen assay: prognostic value in neural crest tumours. Journal of Pediatrics, 88, 591-594.

Gold, P., and Freedman, S. O. (1965). Demonstration of tumour-specific antigens in human colonic carcinomata by immunological tolerance and absorption techniques. Journal of Experimental Medicine, 121, 439-462.

Grigor, K. M., Detre, S. I., Kohn, J., and Neville, A. M. (1977). Serum alpha-foetoprotein levels in 153 male patients with germ cell tumours. British Journal of Cancer, $35,52-58$.

Hasegawa, H., Ise, T., Otsuki, H., Okura, H., and Mukojima, T. (1972). Adriamycin therapy in a child with malignant sacrococcygeal teratoma with special reference to serum alpha-fetoprotein. Japanese Journal of Clinical Oncology, 12, 133-138.

Hasegawa, H., Mukojima, T., Hattoni, N., Sano, R., and Hirota, T. (1973). Embryonal carcinoma and alphafetoprotein with special reference to hepatoblastoma. Alpha-fetoprotein and Hepatoma, pp. 129-139. Ed. by H. Hirai and T. Miyaji. Gann Monograph on Cancer Research 14. University of Tokyo Press, Tokyo.

Itoh, T., Shirai, T., Naka, A., and Matsumoto, S. (1974). Yolk sac tumour and alpha-fetoprotein: clinicopathological study of four cases. Gann, 65, 215-226.

Kohn, J., and Weaver, P. C. (1974). Serum alpha 1 -fetoprotein in hepatocellular carcinoma. Lancet, 2, 334-337.

Lo Gerfo, P., Krupey, J., and Hansen, H. J. (1971). Demonstrations of an antigen common to several varieties of neoplasia. New England Journal of Medicine, 285, 138-141.

Marsden, H. B., and Steward, J. K. (1976). (Editors.) Tumours in Children, pp. 206-217. Recent Results in Cancer Research No. 13. Springer, Berlin.

Masopust, J., Kithier, K., Radl, J., Koutecky, J., and Kotal, L. (1968). Occurrence of fetoprotein in patients with neoplasms and non-neoplastic diseases. International Journal of Cancer, 3, 364-373.

Mawas, C., Kohen, M., Lemerle, J., Buffe, D., Schweisguth, D., and Burtin, P. (1969). Serum alpha-fetoprotein (fetuin) in children with malignant ovarian or testicular teratomas. International Journal of Cancer, 4, 76-79.

Nayak, N. C., Malaviya, A. N., Chawla, V., and Chandra, R. K. (1972). Alpha-fetoprotein in Indian childhood cirrhosis. Lancet, 1, 68-69.

Neville, A. M., and Cooper, E. H. (1976). Biochemical monitoring of cancer. A review. Annals of Clinical Biochemistry, 13, 283-305.

Neville, A. M., and Laurence, D. J. R. (1974). The Carcinoembryonic Antigen (CEA). Present Position and Proposals for Future Investigation. UICC Technical Report Series, Volume 12. Geneva.

Nørgaard-Pedersen, B. Albrechtsen, F., and Teilum, G. (1975). Serum alpha-foetoprotein as a marker for endodermal sinus tumour (yolk sac tumour) or a vitelline component of teratocarcinoma. Acta Pathologica et Microbiologica Scandinavica, 83A, 573-589.

Nørgaard-Pedersen, B., Hertz, H., Sell, A., and Tygstrup, I. (1976). Infantile endodermal sinus tumours (yolk sac tumours) and alpha-fetoprotein. Onco-developmental Gene Expression, pp. 379-385. Ed. by W. H. Fishman and S. Sell. Academic Press, New York.

Obeid, D. A., Hill, F. G. H., Wood, B. S. B., Harnden, D. G., and Mann, J. R. (1978). Fanconi anaemia, oxymetholone, hepatoma and leukaemia (in preparation).

Palmer, P. E., Safaii, H., and Wolfe, H. J. (1976). Alph ${ }_{1-}$ antitrypsin and alpha-fetoprotein. Protein markers in endodermal sinus (yolk sac tumours). American Journal of Clinical Pathology, 65, 575-582.

Pedersen, K. O. (1944). Fetuin, a new globulin isolated from serum. Nature, 154, 575.

Pick, A. I., Schoenfeld, Y., Schreibman, S., Weiss, H., and Ben-Bassat, M. (1975). Alpha-fetoprotein assay. Significance and clinical applications. New York State Journal of Medicine, 75, 1403-1409.

Reynoso, G., Chu, T. M., Holyoke, D., Cohen, E., Nemoto, T., Wang, J. J., Chuang, J., Guinan, P., and Murphy, G. P. (1972). Carcinoembryonic antigen in patients with different cancers. Journal of the American Medical Association. 220, 361-365.

Sakashita, S., Hirai, H., Nishi, S., Nakamura, K., and Tsuji, I. (1976). Alpha-fetoprotein synthesis in tissue culture of human testicular tumours and an examination of experimental yolk sac tumours in the rat. Cancer Research, 36, 4232-4235. 


\section{Mann et al.}

Schoenfeld, Y., Pick, A. I., Schreibman, S., Kessler, H., and Dintzman, M. (1976). Serum alpha fetal protein in a three year old child with hepatoma. Tumori, 62, 407-414.

Shirai, T., Itoh, T., Yoshiki, T., Novo, T., Tomino, Y., and Hayasaka, T. (1976). Immunofluorescent demonstration of alpha-fetoprotein and other plasma proteins in yolk sac tumour. Cancer, 38, 1661-1667.

Takahashi, M. (1973). Cytodiagnosis of primary liver cell carcinoma with reference to alpha-fetoprotein. (In Japanese). Japanese Journal of Clinical Pathology, 21, 769-772.

Tatarinov, I. S. (1964). Detection of embryospecific alphaglobulin in the blood sera of patients with primary liver cancer. (In Russian). Voprosy Meditsinskoi Khimii, 10, 90-91.

Teilum, G., Albrechtsen, R., and Nørgaard-Pedersen, B. (1974). Demonstration of alpha-fetoprotein synthesis in a testicular yolk sac carcinoma by immunofluorescent localisation. Acta Pathologica et Microbiologica Scandinavica, 82A, 586-588.

Tsuchida, Y., Urano, Y., Endo, Y., Ohmi, K., Hashizume, K., Saito, S., Ishida, M., and Hasegawa, H. (1975). A study on alpha-fetoprotein and endodermal sinus tumour. Journal of Pediatric Surgery, 10, 501-506.
Urano, Y., Endo, Y., and Tsuchida, Y. (1976). Alphafetoprotein synthesis in teratocarcinoma: immunopathological studies of yolk sac tumor. Onco-developmental Gene Expression, pp. 131-137. Ed. by W. H. Fishman and S. Sell. Academic Press, New York.

Vince, J. D., McManus, T. J., Ferguson-Smith, M. A., and Ratcliffe, J. G. (1975). A semi-automated serum alphafetoprotein radioimmunoassay for prenatal spina bifida screening. British Journal of Obstetrics and Gynaecology, 82, 718-727.

Waldmann, T. A., and MacIntire, K. R. (1972). Serum alphafetoprotein levels in patients with ataxia-telangiectasia. Lancet, 2, 1112-1115.

Wang, J-J., Sinks, L. F., and Chu, T. M. (1974). Carcinoembryonic antigen in patients with neuroblastoma. Journal of Surgical Oncology, 6, 211-217.

Correspondence to Dr J. R. Mann, Department of Haematology, Birmingham Children's Hospital, Ladywood Middleway, Birmingham B16 8ET. 